\title{
Rastafarian-herbalists' enregisterment of multilingual voices in an informal marketplace
}

\author{
Quentin Williams
}

Department of Linguistics, Centre for Multilingualism and Diversities Research, University of the Western Cape E-mail: qwilliams@uwc.ac.za

\begin{abstract}
What do we mean when we talk about "multilingual voice" in the post-apartheid sociolinguistic context of South Africa? In this paper, I explore this question by reporting on an ethnographic fieldwork project that involved the participant-observation of Rastafarian-herbalists trading goods in an informal marketplace. I focus in the paper on Rastafarian-herbalists' language practices and participation in ideological debates surrounding the ethics of Rastafarian religious practices as they navigate the complex yet regimented linguistic landscape of the informal marketplace in which they trade their goods. Furthermore, I explore in the paper how the marginalized trading lives of the Rastafarian-herbalists are characterized by the daily negotiation of power and diversity discourses as they try to define their voices. Their engagement with diverse multilingual populations, I argue, not only provides them with excellent opportunities to expand their multilingual repertoires, but also teaches them to manage strategically "multilingual voices" in interaction in order to sell their products. I argue further that although we cannot take stock of all types of marginalization, we should develop sociolinguistic approaches that are not only sympathetic to the marginalization of people and languages in the everyday, but also attune our methodologies to accurately capture experiences in small places such as the ones where Rastafarian-herbalists trade.
\end{abstract}

Keywords: multilingualism, voice, informal markets, ethics

\section{Introduction}

This paper is a sociocultural study of multilingual voice. It attempts to weave together, from within the context of the sociolinguistics of globalization, a perspective on linguistic voice that considers how multilingual resources (forms and functions) are taken up in the complexity of multimodal communication in everyday spaces; how language is used to index and to symbolically inject meaning into material objects that are held up for interaction; and how moral issues of a religious nature are talked about and debated by multilingual speakers.

As is clear from the title, this paper is about an informal marketplace context and the Rastafarian- herbalists who trade there. Specifically, I report here on a brief period of fieldwork 
I conducted with Rastafarian-herbalists (for lack of a better hyphenated description) ${ }^{1}$ in an attempt to understand how these multilingual speakers make meaning, draw on language, and talk about their Rastafarian identity in an informal marketplace defined by diversity. I was particularly interested in demonstrating how Rastafarian-herbalists use local language varieties such as Kaaps (a variety of Afrikaans) and isiXhosa to "call out" (Bauman 2001) and sell their herbal products as they as enregister discourses of Rastafarianism and assume the identity/identities of herb sellers. I was also interested in how these herb sellers enregister transnational language varieties, such as Jamaican Patois, mixed in with English and Kaaps to debate and prognosticate to each other of the local contingencies that define Rastafarian moral principles in the everyday, parallel to how they manage the flow of people and languages in the small spaces where they enact multimodal communication as they attempt to successfully sell their herbs.

This paper is inspired by ethnographic fieldwork studies on language in markets and aims to develop such literature by spotlighting the local permutations of multimodal communication by multilingual speakers. It illustrates how they encounter each other and make meaning in small, local spaces, not only through the use of mobile linguistic resources such as language varieties and registers but also through physical indexicalities such as gestures, body positioning and other non-verbal modes in communication (see for example Bauman 2001, 2004; French 2001; Farfan 2003; Kapchan 1996; Lindenfeld 1978; and more recently Pennycook and Otsuji 2015).

In what follows, I contextualize the paper within the context and scholarship of sociolinguistics of globalization studies to suggest the idea that the small spaces in which Rastafarian-herbalists practice their selling of herbs and do multilingual and multimodal communication are not only defined by the processes of globalization but also by the local moorings of multilingual mobility (through the movement of people and objects), senses of place and the local indexing of space. To analyze the multilingual practices of the Rastafarian-herbalists, I apply the notion of 'enregisterment' in order to demonstrate how particular cultural stereotypes of voice and cultural models of personae are held up as important resources for the successful enactment of multilingual and multimodal communication. To such an end, the notion of 'enregisterment' anchors the paper conceptually and frames the data analyses.

The data analyzed in this paper illustrate that the enregisterment of Rastafarian-herbalists' multilingual voices involves a sensitivity to mobility, space and bodies: all resources in the mediation of multimodal communication and the conveying of a multilingual simpatico to their customers, but also resources to put on display their own voices, whether it is through multilingual calls (see Haviland 2009, 2011), making sense of the cultural links between multilingual forms and multilingual practices, or engaging in heated debates of moral issues pertaining to the practice of Rastafarian religion. Thus, I illustrate the former and latter through two sets of data: (1) multilingual interactions with a Rastafarian-herbalist, and (2) a turbulent multilingual moment that sees the reassertion of Rastafarian moral principles through a

\footnotetext{
${ }^{1}$ Throughout the paper, the reader will encounter this use. The reasons are as follows: when I first introduced myself to my research participants, they looked outwardly like Rastafarians, as they wore dreadlocks, clothed themselves in the Ethiopian flag, greeted and gestured to each other according to Rastafarian practice and religious code, and called themselves "Rastafarians". No aspect of this description has changed. But at the same time they referred to themselves as "herbalists", hence the hyphen, and very often they called themselves "herbal doctors" and "herbal specialists" because they assumed that the sale of herbs does not only involve describing what the herb is, but also informing the customer how, how often and for how long to use it.
} 
transnational language variety and a local language variety. Both examples point to the importance of multilingualism as a significant resource for multimodal communication in small spaces, and, specifically for the Rastafarian-herbalist, the sale of a herbal product. I conclude the paper with a discussion of the importance of multilingual voice for multilingual identity in an increasingly globalized world where small spaces for multilingualism matter as much as big, expanding and densely-networked spaces.

\section{Multilingualism in a globalized world}

The study of multilingualism in a globalized world presents new opportunities to theorize how linguistic voice is shaped in the processes of globalization (localization, delocalization, decontextualization and recontextualization). Globalization has certainly thrown new light on the manner in which multilingualism takes place in various localities across the world, because it constitutes "both a social mode that we need to keep probing and... a focus for some new ways of understanding language in society" (Coupland 2010:2). As Blommaert (2003:608) argues, in the processes of globalization "what is globalized is not an abstract language, but specific speech forms, genres, and forms of literacy practices".

In times of globalization, the conditions for a qualitative change in the practice and performance of multilingualism are often likely to arise. In transformative societies such as South Africa, to do multilingual communication is to recognize that language contact more than ever also involves contact with styles, registers and repertoires of speech practices that have been honed in cross-cultural situations and spaces. The social life of multilingualism is important for individuals and groups, particularly in the use of multilingual repertoires as tied to voice. The dictates of social life, particularly in times of globalization, have meant that new conditions have arisen for the "maintenance and development of various kinds of multilingualism" (Heller 2007), and this has meant that we have moved into a new global definition of multilingualism as a phenomenon of "... sets of languages, rather than single languages, [that] now perform the essential functions of communication, cognition and identity for individuals and the global community" (Aronin and Singleton 2008:4; see also Blommaert, Collins and Slembrouck 2005; Gardner and Martin-Jones 2012).

It is because of the linguistic opportunities presented by globalization that multilingual speakers see their language and speech practices as uniquely linked to their pursuits of global and local life trajectories and the bringing together of communication systems that comprise diverse linguistic and semiotic resources. Multilingual communication is thus a part of the world of flows, to invoke Appadurai (1996), and the way it is organized in globalization allows us to view how the distribution of linguistic resources is coupled to the scaling of small multilingual spaces (Aronin and Singleton 2008:7).

Thus, the rapid changes we observe in globalized societies today have had significant implications for the way in which groups and individuals do multilingual communication. Often we fail to document how speakers use multiple languages to define their lived experiences and their social spaces. For many multilingual speakers, linguistic choices not only determine their mobility but also what benefits they may reap from the array of interactional settings around them (Weber and Horner 2011). 
But in a transformative society such as present-day South Africa, what does it mean to engage as multilingual speakers in multilingual communication in small spaces? How are linguistic and non-linguistic resources performed and practiced in such spaces? And how is multilingualism linked and enregistered to linguistic voice?

\section{Enregisterment of multilingual voice}

Multilingual voice as tied to the practice of multilingual forms and functions is important to the everyday communication practices of multilingual speakers. Multilingual speakers draw from their repertoires to make linguistic associations and, as a result, enregister to personae, personalities, cultural lifestyles, space and place. To enregister is to recognize and be engaged in a process where a certain register, a linguistic repertoire (Agha 1999:216) that is linked to cultural and social practice in interactions, performances and practices, is given social value in social contexts.

Agha (2007) characterises enregisterment as a process whereby linguistic forms come to indexically represent particular social values as the result of the circulation and uptake of linguistic forms across various modalities and media. A number of recent studies have used enregisterment as an analytical concept to understand the practice of language and multilingualism in performance (see Roth-Gordon 2009); the processes involved in determining whether one dialect or variety as a register is accorded higher status than others through metapragmatic activities (Dong 2011); how language varieties index politics and citizenship (Newell 2009); and the enregisterment of identity in multilingual settings (Goebel 2011). All of these studies implicitly or explicitly demonstrate how linguistic voice is put forward through cross-cultural and cross-racial interactions.

In this paper, as I will demonstrate below, the notion of 'enregisterment' is a useful analytical tool to the extent that it offers us insights into how interactions between multilingual speakers in small spaces on different social and cultural occasions are focused on meaning-making, the presentation of voice, and the performance of personae.

\section{Ethnographic fieldwork and analysing multilingual voices in small spaces}

The project I report on in this paper is based on short ethnographic fieldwork (following Blommaert and Dong 2010) which lasted approximately three months. Ethnographic fieldwork was found to be a useful approach because it allows the researcher to make sense of the global forces emerging and interrupting longstanding social and traditional routines in small multilingual spaces.

Ethnography is a form of knowledge and a way of gathering knowledge; an ontology and a methodology (Geertz 1975). As an ontology it leads us to expect that the world is made up of practices and semiotics. And as a methodology in its incipiency, ethnography is typically but not exclusively seen as involving the collection of a variety of information by means of what are commonly referred to as "field techniques", such as note-taking, audio-visual-recording, interviews, and observations, as well as participant-observation of random and mundane social and cultural activities (Gupta and Ferguson 1997; and cf. Malinowski (1922/1961) who spent two years conducting fieldwork in the Trobriand Islands). What the ethnographer does is offer the reader "thick description" of a world probably unknown to her or him (Geertz 1975:6). 
Thrust into the fray of others' cultural and traditional assortment, the ethnographer gradually consolidates but never faithfully synchronizes what he/she and the other share (Fabian 1983).

In a multilingual world shaped and reshaped by the processes of globalization, ethnographic fieldwork helps us to document social and linguistic contact phenomena on the move. Ethnographic fieldwork also allows for the collection of multilingual data, in the case of this paper, that provide fascinating insights into the practice and performance of multilingual practices that are said not only to be local, but also global. Thus, in order to understand and document how multilingual speakers, particularly Rastafarian-herbalists, enregister their multilingual voice, I observed and documented multilingual interactions and sociolinguistic trajectories in the small spaces as a way to build on ethnographic studies framed within the scholarly context of the sociolinguistics of globalization (Blommaert 2010; Collins, Slembrouck and Baynham 2010).

In the next section, I first introduce the research project and thereafter illustrate how my research participants navigate the urban space through language and conversations about sensitive ethical issues. I will do so by also reflecting on my voice and my role in the data collection process, as well as my presence and absence in the data transcriptions.

\subsection{Context: Trading above and below Bellville's marketplace}

Bellville is an urban space that lends itself well to an analysis of the material semiotics of entanglement. As a city space uniquely positioned for global economic trade, Bellville can be defined as a porous place constantly made and remade by migration, mobilities and consumption practices. It is the destination for transnational migrants and various formal and informal businesses (Gastrow and Amit 2013). It is also a vibrant cultural city; host to various multilingual activities and performances. This is the empirical basis on which we decided to design a material ethnography study that could account for how community practices, the material manifestation of multilingualism, and social networks are closely tied up with the economies of spaces of consumption in Bellville.

Bellville railway station, also known as "Bellstar Junction", is the second-largest train station in the Western Cape, and is a major intermodal transport hub in the region. The station precinct is an important thoroughfare for the local Metrorail train service and the national Shosholoza Meyl train service. Commuters who rely on the train services also make use of other forms of transport, for example buses at the bus terminus and minibus taxis at the minibus taxi rank.

Commercially, Metrorail and Shosholoza Meyl are key tenants of Bellstar Junction. The financial viability of other tenants in the station is largely dependent on the presence of these two enterprises. The large majority of people who walk through Bellstar Junction are commuters who board and alight from the trains serviced by Metrorail. During our fieldwork we observed how commuters bought their tickets and interacted with sign artefacts at the Metrorail ticket offices located within the centre of Bellstar Junction. The mobility of commuters through Bellstar Junction provides important business for the surrounding restaurants, clothing stores and fast-food outlets.

Bellstar Junction became the central focus of my fieldwork where I collected data for three months, from June to August 2012. I would like to argue that while the fieldwork I conducted 
does not constitute an ethnographic study per se, the process I followed to connect with my research participants and the manner in which I collected the data - through participantobservation, interviews, video and audio recordings - constitute methods of ethnographic fieldwork. I began fieldwork by first observing how informal traders, for the most part, erected their stalls and positioned their products in the early winter mornings in June. Then, working as part of a team of ethnographers interested in the use of language in the market area of Bellville, I followed traders who were pushing heavy trolleys of goods as they stopped, unpacked their goods, and strategically positioned them in such a way that they would attract potential customers. I often observed movement of people in the early morning, and it was amidst the organized rhythmic chaos of public transport commuters where I chose to adjust my objectification lenses on the market practices and performances of Rastafarian-herbalists (while the other members of the team focused on the lived experiences of Somali and other African migrants).

I met one of my research participants trading herbs with a fellow Rastafarian-herbalist outside Bellstar Junction. At the time, I approached them and introduced myself as a researcher from the university conducting fieldwork in the marketplace of Bellville. I spoke Kaaps, the language that both participants spoke. I described at length what my research project was about, and afterwards they explained to me some of the herbs and their meanings as well as their usage. I did not video- or audio-record their interactions, but I asked permission to take a picture of their herbs and they in turn asked if they could pose. I was later introduced to an older Rastafarian, who, though he did not trade herbs in Bellstar Junction, traded in snacks, sweets and other types of everyday consumables that commuters would be interested in. His stall is stationed at the top of a staircase leading down to the train station subway. It is he who introduced me to the other Rastafarian-herbalists who would become the central focus of the study: Jeremy and Jaak.

After I had also introduced my study to the rest of my participants, I used a small camera placed in my t-shirt pocket to record interactions between the herbalists and potential customers. This was done because initially I encountered great difficulty taking photographs in the subway, given the poor lighting and other traders' general suspicion that I may have been part of focused colluding and overhearing (Goffman 1981:134) often employed by the police regimenting the marketplace.

During this process of the data collection, I became aware of the fact that while I did not share the Rastafarian or herbalist identity of my participants, we did share a racial identity, coloured; and spoke Kaaps as a first-language variety. And while my Rastafarian informants spoke in addition Jamaican Patois and a variety of English, we all shared Kaaps as a working-class community language. Our bodies have been historically racialized. I used this marker of working-classness to initiate not only contact with the Rastafarian-herbalists but also to establish a simpatico with the cultural and lived circumstances and experiences of my informants as they navigate the informal and formal market structures in Bellville's Central Business District. Kaaps is a historically marginalized variety of Afrikaans (Hendricks 2012); a speech variety that is not, according to Adam Small, Gammat-taal ${ }^{2}$, but a first language for many so-called "coloured" and Malay people of Cape Town (Small 1972:99; Small 1987:83-4; Hendricks 2012; Blignaut 2014:45).

\footnotetext{
${ }^{2}$ Gammat is an Afrikaans term, typically considered to be derogatory, referring to a young person of so-called "coloured"/Malay descent.
} 
Rastafarianism in South Africa has its roots in the transnational flows of Ethiopianism, based on the principles and beliefs of the Ethiopian King Hale Selassie, on the one hand, and Garveyism, based on the decolonial principles offered by Marcus Garvey, on the other (see Oosthuizen 1990; Bosch 1996). "Rastafari" is derived from Hale Selassie's birth name "Ras" (meaning "Prince" in Ethiopian) and Tafari Makonnen. Rastafarianism, or Rastafari, is a religious and political movement which, like all the liberation movements (the African National Congress, United Democratic Front, etc.) fought against apartheid. In its present-day practice, Rastafarians still preach the unification of African people as expressed in the principles of Garveyism (Chawane 2012:17). Their ethical principles are still based on twin ideologicoreligious pillars, Ethiopianism and Garveyism, which both emphasize the enlightenment and freedom of Africans from post-colonial hegemonies; that is, they advocate emancipation from both colonial powers and from postcolonial hegemonies. Music, particularly reggae music, defines the outward cultural and religious practices of the Rastafarian, and as part of a religious movement the Rastafari is guided by the following religious ethical practices (Tolsi 2011): She or he shall at all times read, cite and perform the scripture in the "Holy Piby", which is the name given to the Holy Bible (King James Version) and the recitations/teachings of Haile Selassie; the Rastafarian shall worship in his house once a month on Saturday; she or he shall partake of the holy herb (marijuana) at Nyahbinghi Holy gatherings; no Rastafari under the age of 18 shall smoke the herb without parental guidance; every Rastafari shall marry; members shall not be punished for wearing dreadlocks; and no polygamy or fornication is allowed under any circumstances (summarised in Chawane 2012:181).

The interactional and linguistic data analyzed below are taken from recorded conversations between two Rastafarian herb sellers who became my main informants: Jeremy and Jaak. Jeremy, an older and mature Rastafarian-herbalist, has been trading for a while in the subway. $\mathrm{He}$ is a respected Rastafarian, even though he has been imprisoned for petty crimes. He is a devout Rastafarian, so much so that he has tattooed across his neck the word Sakman ('sackcloth man'). A sackcloth man is a Rastafarian initiate in the process of converting to the Rastafarian religion. He lives a nomadic lifestyle in the woods of Cape Town and is always seen barefoot, dressed in sackcloth. Jeremy was once a Sakman, but due to precarious circumstances, he and his family had lately fallen on hard times. By day he trades herbs in Bellstar Junction's subway, and by night he finds a place for him, his wife and his daughter to sleep. His wife also trades sweets and other consumables. Jaak is younger than Jeremy and commutes to Bellville on a daily basis. He lives in Bellville South and has been mentored by Jeremy for the last few years. Unlike Jeremy, Jaak does not have a wife, but has a child and a permanent domicilum. He used to trade herbs outside of Bellstar Junction, but with the help of Jeremy he found a permanent station on the floor of the subway where he and Jeremy roll out a mat and pack out their herbal products.

Linguistically, Rastafarians in South Africa and particularly Cape Town are multilingual devotees. Like the origins of Rastafarianism, Rastafarian language (or "Dread Talk", see Manget-Johnson 2008) is a mixture of local and heritage languages. In other words, the multilingual repertoire of a Cape Town Rastafarian would typically reveal a multi-variable and highly stylistic use of the heritage Jamaican Creole and Khoi languages; language varieties such as isiXhosa and isiZulu; and Kaaps (a variety of Afrikaans, and possibly a first language for many Capetonian Rastafarians), English (possibly a second language), Sabela and Tsotsitaal, and so on. Sabela is the prison register, and Tsotsitaal is a stylect commonly used by the Number gangs and coloured and black males on the Cape Flats of Cape Town. In my data sets, I have 
found that my research participants typically use Jamaican Creole Ihi yahnh Ihi or InI (meaning 'I and I', 'we', or 'you and I'), Jah ('God'), Iya ('my brother'), and Amigideon (a name appearing in the book of Revelations in the Bible that not only describes the state of the world but also the meaning Rastafarians attach to that word).

No sociolinguistic literature exists to date that hints at or comprehensively reports on the language practices of Rastafarians; nor are there studies that have described their languages. One main reason for this is, I argue, that sociolinguistic scholarship has been preoccupied for much of its institutionalization with describing Englishes in South Africa, and to some degree other varieties. Rastafarian language practices of course are marginal by practice and have not warranted the intellectual and epistemic attention of sociolinguists in the country. In this context, I as a scholar of language and researcher of multilingualism have been unempathetic and uninterested in changing my linguistic vision of such speakers, but this paper is an attempt to remedy my intellectual position.

The actual data I report on below were all collected in the setting of the subway tunnel of the station area at Bellstar Junction. I chose this setting because it emerged in my fieldwork that the everyday interactions of Rastafarian-herbalists are monitored and regimented by law enforcement employees of the City of Cape Town in Bellville marketplace. In the time during which I conducted fieldwork in this area, I tried to tune in to the sensory experiences of the Rastafarian-herbalists by training my eyes and ears, indeed my 'whole sensorium', to capture the true essence of my participants' multimodal communication. I did so in the hope that I would grasp their linguistic repertoires and heteroglossic life moments of herbal trading and transpose into writing the carnivalesque spirit of Bellville's informal marketplace.

In the next sub-sections, I demonstrate exactly how, in the very small linguistic details, herbal trading occurs in small spaces; and I demonstrate how enregisterment of Rastafarian-herbalist personae is performed.

\subsection{Calling out herbal products in multilingual voices}

Herbal trading in the marketplace of Bellville is a tradecraft with a wide provincial network that involves mostly male workers. It is a type of interaction where male herbalists prodigiously mix and perform genres and discourses of the Rastafarian religion to which they belong (compare the merolicos in Haviland 2011). They are challenged to attract passers-by, so they may assume the status of 'a customer'. Faced with reluctance and suspicion, Rastafarianherbalists accentuate their potential customers' multilingualisms by sounding out their products and further frame their assumption of multilingual practices as wrapped in mobile speech events (multilingual speakers walking past their mats of herbs on the ground and the larger soundscape in the market) in which they engage on a daily basis. They do so by adjusting to body comportments: gazes, movements and languages as indices of interest (Lefebvre 2004).

For Rastafarian-herbalists to sell their herbs in the subway tunnel, they have to 'call' out information about their products. They have to perform calls. According to Lindenfeld, "calls" are part of product performances that are very elaborate in marketplaces, offer quick but useful information about products (a feature or recognizable characteristic), and draw "people's attention to the sender" (Lindenfeld 1990:69). They serve as a verbal advertisement, a sound bite promoted by sellers who shout out what to buy at a particular stall in the marketplace. Calls 
are short, and their purpose is for people who hear them to identify with a particular product they need and are searching for, and for them to move towards the call. Calls advertise a particular product, the price of the product, and usually comprise one or two words or at best a lean phrase. A call accompanies the use of non-verbal resources such as gestures, pointing, gaze and "multisensory process[es] that combine verbal and visual appeal" (Bauman 2001:62). For example, one of my research participants would call out the herbs for sale in the following way, and often in quick succession:

\author{
1. Fresh Herbs! 3,4 \\ 2. Fresh Herbs! \\ 3. Zonka Amayeza! ('All the herbs') \\ 4. Zonka Amayeza! ('All the herbs') \\ 5. Higher Grade, Tjommie?! ('Marijuana, friend?!') [looking at a male passer-by] \\ 6. Higher Grade?
}

The above examples illustrate that when the herbal seller cries "Fresh Herbs!" (lines 1 and 2), it requires repetition of a model two-word combination in English. The same is done in isiXhosa (lines 3 and 4), but the translation reveals that whereas the crying out of the sale of "Fresh Herbs" is very specific in its meaning, referring to freshly-collected herbs, the crying out of Zonka Amayeza is much more general. Interestingly, certain call pairs or word combinations comprise more complex forms, as is the case with crying out "Higher Grade" (marijuana) followed by a referent or an addressee, Tjommie ('Friend') (pronounced in Kaaps). (The term "Higher Grade" was invented by Jaak and possibly his fellow Rastafarians, and its mere uttering to passers-by or regular marijuana users indexes to them the availability of the product from Jaak or Jeremy. "Higher Grade" is thus a common label for marijuana.)

These short calls serve as product verbalization and are open to lengthening as herbalists elaborate on the features and characteristics of herbal products. Bauman (2001) has demonstrated that opening up on or providing more information about products requires 'syntactic extensions' that arise as declaratives and are enough to lure in potential customers because the calls almost always remain 'consensed', 'syntactically lean' and therefore subject to repetition. For example:

1. Zuka gaba ('herbs for vomiting'), mamma, herbs for the stomach!

2. Herbs for the sickness!

3. Hierso, zuka gaba ('here, herbs for vomiting'), high blood pressure!

4. Gesonde kruie, vir alle kwale, jonga-jonga! ('fresh herbs, for all ailments, look-look!')

\footnotetext{
${ }^{3}$ Transcription convention:

Fonts representing accents and language varieties

- Kaaps

- A variety of South African English

- Isixhosa

English translations are provided in italics in round parentheses, and additional information is provided in italics in square parentheses.

${ }^{4}$ In this example, the call is uttered by one Rastafarian-herbalist.
} 
The multilingual calls given above have a specific structuring purpose for herbal product presentations, and what I discovered is that the onus rests on the herbal trader to successfully present his herbal product. This is accomplished through calls initially but also by listening to customers' languages, studying their body language, and tracking their gaze. In what is to follow, I look in detail at how Rastafarian-herbalists do multilingual interactions with their multilingual customers, followed by debates about Rastafarian religious ethics. In the first subsection, all the excerpted transcriptions hide the fact that even though I am not present or explicitly interpellated in these transcriptions, I am nevertheless present and in close proximity to the herbalist and the customer. The reason that I am not explicitly mentioned is that I could only hold the recorder near the space of interaction of my informant and his customer without preventing the successful completion of a sale. If I moved any closer, I would have interrupted the interaction and possibly the sales transaction. In the second set of excerpted transactions, I am fully hailed, verbally and non-verbally, because I was part of the interaction and in the interactional circle.

\subsection{Multilingual interaction with customers}

One morning I observed how more than three customers approached Jaak to inquire and to buy particular herbs. The first customer was an old lady who approached the mat slowly. The reason for this was that at the precise moment she came near the mat, the subway filled with passengers running, walking slowly and rushing from one platform to the next. Thus, she came as a surprise to Jaak. But he jumped up and immediately initiated contact, choosing his language and accent carefully (to enregister his Rastafarian-herbalist persona) and slowing down his body so as to enunciate at a slower pace information about the herb after which the customer had inquired.

Extract 1: (Participants: Jaak; F1: Female 1; F2: Female 2)

1. Female 1: [walks slowly up to Jaak, bows down and makes a request] [Inaudible]

2. Jaak: [Jaak, seated next to me on the floor, stands up to walk over to the other side of the mat to fetch a herb and shows it to the customer. I, the Researcher, also stand up and close to Jaak and the F1 start to record the interaction]

3. Female 1: How much is this?

4. Jaak: Unozi? ('Herb?') A piece is ten rand.

5. [Talking between J and F1 drowned out for a few seconds because of increased number of pedestrians walking past]

6. Female 1: Huh? [Watching how Jaak is cutting the herb]

7. Jaak: Tien rand . Ten rand.

8. Female 1: [Picks up the herb. Points at it] This is Nonkwe (a local herb)?

9. Jaak: [Jaak smiles and agrees] It's this one yes.

10. [Noise level increases again from passing pedestrians walking from one platform to the next]

11. Female 1: Oh, you cut it. Ok.

12. Jaak: [Jaak proceeds to pick a brown paper sheet, cuts the herb again, and shows this to the customer]

13. Female 1: Where is your brother that was here?

14. Jaak: Jeremy?

15. Female 1: Yes

16. Jaak: In Jail Rasta. 


\section{Jaak: This one is from Knysna and this one comes from P.E. \\ 18. Female 1: [inaudible] \\ 19. Jaak: Yes, they have the same purpose \\ 20. Female 1: [inaudible] \\ 21. Jaak: [Wraps up paper sheet and hands it to F1, when another customer, F2, walks swiftly into view]}

From lines 1 to 11, the customer only asks about the herb: she points to it and allows Jaak to briefly mention its name. She is a returning customer. This is evident when she asks Jaak, in line 13, about the whereabouts of the "other Rasta". And Jaak replies "Jeremy", to which the customer replies in the affirmative. However, at about the same time, the subway is filled with noise, but a second later Jaak forces out his enunciation of the geographical origins of a specific herb in question. The interaction between him and the black female customer is accomplished in English, but as will become clear below, the arrival of a coloured female customer (F2) requires the herbal trader to shift swiftly into a position where his body and gaze are able to keep all three customers interested in the purchase of herbs.

Jaak is about to finish the sale to F1 by wrapping the herb in a brown paper sheet (line 21 above) when a second customer (F2: the second female) arrives. She hovers around hoping to get Jaak's attention, but decides to walk away as quickly as possible. Jaak realises this and shouts: "Haah mamma don't run! Don't run mamma!". He immediately secures the slowing down of the second customer, but at that moment two policemen come walking down the subway slowly and scare the CD and DVD traders into a run. Amidst this commotion, Jaak keeps his body position and gaze fixed in the area of the customer; his eye contact is fixed on the second customer, while dealing with the first customer. The first customer, F1, moves to the background and changes her role from a potential customer to a silent overhearer, a visible eavesdropper; hoping she is able to interject or interrupt the exchange. Given this change in position, the second customer assumes the stance of herb buyer and decides she wants to initiate interaction with the hope of purchasing the correct herb. She proceeds to instruct our herbalist in Kaaps.

\section{Extract 2:}

24. Jaak: 'n Garlic? ) [pointing]. 'n Bossie knoffel? ('A garlic?') [pointing] ('A bunch of garlic?')

25. F2: Moet ek dit sterk aan maak of vlou? ('Do I need to make a strong or flimsy mix?')

26. Jaak: Sterk! ('Strong!')

27. Jaak: [indicating whether he should give a different herb]

28. F2: Net afsny van dai ) [pointing]

('Just cut from that')

29. Jaak: Bietere om te raspe. Mammie raspe vir hom ) [pointing] ennie [inaudible] wortel. Helfte van die [pointing to the herb] en mak die annes oek soe.

('It's better to grate it. Mother grate this one [pointing] and the root. Just half of this and also do this to the other one as well.')

30. F2: Hoeveel is dai?

('How much is that?') 
31. Jaak: Die is twintig rand.

('This is twenty rand')

32. F2: Hoeveel?

('How much?')

33. Jaak: Twintig.

('Twenty')

34. Jaak: [opens brown paper sheet to package of the herbs]

35. F2: Moet ek nou alles dai aanmaak?

('Must I boil everything?')

36. Jaak: Alles ma. [Shaking head up and down to make yes gesture]. Mamma vi' alles ingooi. Vi' hulle twie raspe [pointing to the herbs] en inmeng en vir hom [pointing to herb and making a cutting gesture] in die helfte.

('Everything ma. Mamma must boil everything. These two you grate and mix and this one you cut in half.')

37. [A third customer, male, arrives and enquires about a specific herb.] [Jaak says he doesn't have such a herb - audio inaudible]

Thus, we see here that the herbalist uses the honorifics ma and mammie (in Kaaps) and mamma (in accented isiXhosa) in the course of the interaction. This is a frequent verbal gesture, I found in my data, of respect used among herbal traders as they address older women who buy their herbs. But in this case, I note, the use of $m a$ and mammie is reserved for the coloured customer who conducts the sale in Kaaps, and mamma is stylized because our herbal trader is aware of the first customer who is a mature black female.

Specifically, from lines 24 to 29 Jaak instructs Female 2 how to ready the herbs for use. Because she is older than him, he does not use the informal referent djy 'you', but prefers mammie (djy is widely used by Kaaps speakers in informal situations, but the choice the herbalist makes here is to use a more respectful reference from his multilingual repertoire). Whether done consciously or unconsciously, on the one hand he breaches the private use of mammie (often used with endearment) and uses it in a very public place, in an attempt to manage the linguistic diversity of customers flowing his way. On the other hand, his use of the word may be evidence of contact with isiXhosa and Xhosa culture, in which it is polite to use mama as an honorific in public. This introduces a sort of linguistic complexity into the multimodal interaction between the herbalist and the customer, which ties "in their overall configuration" (cf. Bauman 2001:77) in the use of sales genres and language at the same time. After a momentary discussion of the price of the herbs (see lines 30 to 35), Jaak then addresses Female 2 as $m a$, followed by the use of mamma in accented isiXhosa (presumably to acknowledge Female 1 who is still part of the interactional space). The use of mamma and mammie not only indicates a shift in interaction, but also constitutes a series of realignments with the customer to connect on a respectful level. In other words, here we see the herbalist personalize the interaction as a way to demonstrate that he is a respectable seller of herbs. The herbalist assumes an affective stance as opposed to an epistemic one (cf. Jaffe 2009:7): he moves from explaining the herbs and using his knowledge of herbs to describe their use and value to tapping into the politics of respectability with his customers.

To summarise, it is clear that Jaak, our Rastafarian-herbalist, is an acute linguistic observer of everyday interaction and has mastered the way he communicates with his customers. His successful command of Kaaps, English and words in isiXhosa is an indicator of his multilingual 
repertoire and use of multilingualism. He relies on these languages to successfully execute a sale of a herb and to keep his customers' attention so that they may eventually part with their money. In the next section, I describe and analyse interactions where I am a full participant in the interaction.

\subsection{Multilingual ethical debates in the subway tunnel}

The second piece of data analysed in this paper begins with an event enacted by one Rastafarian who violates or flouts Rastafarian religious ethics. This event is followed by a debate that involves the research participants, the two Rastafarian-herbalists, the researcher and another anonymous Rastafarian-herbalist defending his 'brother'. But what had happened initially? One afternoon, as my research participants were busy trading their herbs, a young Rastafarianherbalist came into the subway and walked swiftly past us. Not a minute later a prostitute walked past us. I only came to understand this at a later stage, but at that moment Jaak, seated next to me, jumped up and shouted furiously, Hy gaan nou weer lê! Sy soek net drug geld! ('He's going to have sex again! She's only doing it for drug money!'). Both my research participants ran toward the one end of the subway a couple of minutes later to confirm whether the young Rastafarian-herbalist was indeed engaged in coitus, and indeed he was.

I had not realized it at the time, but the young Rastafarian-herbalist broke a fundamental religious law and principle of ethics that Rastafarians abide by, never mind not being actively engaged in the sale of his herbs: that is, "no fornication is allowed" (Chawane (2012:181), see also the discussion above of Rastafarian ethics). He had willingly solicited sex from a prostitute and gone against the ethical principles outlined by the Rastafari National Council's Constitution of the Nyabhingi Order (summarised in Chawane (2012:181), see also above). Moreover, he was a young initiate, 'n sakman ('sackcloth man'), set on the path of spiritual redemption and religious conversion. This made his ethical violation even more reprehensible. Though he did not care about his act, my participants did, and threw scorn at him when he passed back through the subway tunnel. The moment he passed by we began to form an equidistant circle and to talk about the unethical acts of the young sakman Rastafarian. At that moment a fellow Rastafarianherbalist passed by (a friend of the young Rastafarian), prompting Jaak to respond:

\section{Extract 1}

1. Jaak: 'n Sakman my broe. 'n Sakman.

('A Sackcloth man my brother. A Sackcloth man.')

2. Rasta 1: InI kan nie nog judge nie. Iya, sien die man. Al wat Iya kan vra is virrie Lord te vra Iya, sien die man, om dai man se ways te kan change. (looks at Researcher) ('We can't just judge. My brother, you see. All that we can do my brother is to ask for the Lord my brother, you see, to change the ways of that man') [looks at researcher].

3. Researcher: Ja (nods to acknowledge)

('Yes')

4. Rasta 1: En, en, en, en...om dit, en, en, en het nie. Dit het nie met InI gebeur nie Iya. ('And, and, and, and.... because, and, and, and it's not. It did not happen to us Iya.')

5. Researcher: Mmm. Ja, ja.

('Mmm. Yes, yes.') 
6. Rasta 1: Dit is nie InI wat soe wegdwaal van die way nie Iya, van die Lord nie Iya. Over die man? [looking at researcher]

('It's not we that strayed from the path my brother or from the Lord my brother. Can you understand?')

7. Researcher: Mmm...ek verstaan.

('Mmm...I understand.')

8. Rasta 1: versterk vir Iya, want hoekom Iya, hy is weak Iya. Over die man? En een en elkeen van ons kan soe [inaudible] raak. Sien die man. Ons pray vir maar vir hom Iya.

('Stay strong my brother, because my brother, he is weak my brother. Can you understand? Each one of us can become like him. You see. We have to pray for him my brother.')

9. Jeremy: Nou djy sê, een en elke ding...vir Vader Jakob gesit dit op die aarde.

('Now you say, each and every thing...for Vader Jacob had put them on Earth.')

10. Rasta 1: Is net soe Iya.

('Just like that my brother.')

11. Jeremy: Hy maak my naam swak gemaak. Ek is nie, Ek is nie Reuben nie. Ek is voor hom gebore. Ek is die tweede gebore, hy is die 7de gebore. Verstaan djy? [inaudible].

('He weakened my name. I am not, I am not Reuben. I was born before him. I was born on the $2^{\text {nd }}$ and he is on the $7^{\text {th }}$. Do you understand?')

Jaak's accusation in line 1 above stops Rasta 1's brisk walk through the tunnel and he turns around to assert that the actions of the young sakman are not representative of the larger group of Rastafarians trading in Bellville's informal marketplace. His halting of his physical movement, as we soon found out, is done to assert a moral principle and the moral beliefs of Rastafarians generally: that is, to uphold the spiritual and moral ideals of Rastafarianism and to correct any misunderstandings that derive from it. His goal was to school us on the politics of Rastafarian morality and respectability.

As Rasta 1 entered the circle, he looked at me and I acknowledged him with a "Yes" and a nod (line 3). He then proceeded to state that what had happened to the young Rastafarian had not happened to Jaak (line 4), to which I reply self-consciously with a backchannel "Mmm", followed by an acknowledging "yes, yes" (line 5). My response betrays my involvement in the interaction, not because I stand in the circle, but because I participated in subtly commenting on the turbulent ethical event involving the young Rastafarian that had become the topic of the conversation. He looks at Jaak and then at me and says that it is neither I nor Jaak or any Rastafarian that has strayed away from the way, i.e. the Lord; but rather the young Rastafarian (line 6). In the same line, he then asks if his Rastafarian brother understood what he was saying: Over die man? To over or overstand in Rastafarian language is not to simply understand, but to appeal to a speaker's enlightenment through spiritual knowledge and to a person's moral consciousness of a particular topic. Thus, as Rasta 1 glances over to me, I respond that I understand ( $e k$ verstaan, line 7), clearly naïve and not knowing the denotational value of overstand. I of course misunderstood the indexical meaning of overstand that Rasta 1 appeals to. Nevertheless, as our conversation continues, Rasta 1 starts to appeal to the strong moral qualities of his fellow Rastafarians. As such, he begins to make the case that the young 
Rastafarian is weak and that nobody is impervious to weakness (line 8), and that we have to pray for each other.

But this defence by Rasta 1 is insufficient for Jeremy, because the act of the young Rastafarian is a direct offense to Father Jacob (Vader Jakob). The reference here to Father Jacob refers back to the progenitor of the twelve tribes of Israel. Israel (meaning 'rebel'; literally "He strives with God", cf. Genesis 32:28, ESV), as Jews, Christians and Rastafarians believe in accordance with the Biblical tale, is the name given to Jacob after he wrestled an angel who turned out to be God. More specifically, Jeremy accuses Rasta 1 of generalizing weakness, and says that everybody and everything that Father Jacob put on Earth is weak (line 9). Rasta 1 agrees that it is so, but then Jeremy retorts and states what would seem to be a personalization of the ethical violation of the young Rastafarian: he argues that his name has been insulted (line 11) and that he is not a Reuben, that is to say, from the tribe of Reuben (one of the 12 tribes of the house of Israel), but of the tribe of Asher (one of the sons of Jacob (Israel) and the name of one of the twelve tribes of Israel) (see Extract 2 below); born on the second day, five days before those born in the tribe of Reuben (on the seventh day) ${ }^{5}$.

\section{Extract 2:}

29. Rasta 1: Maar moet nie vergiet nie $==$ ('Don't forget') $=$

30. Jeremy: $\quad==$ Nai, nai, nie. Ek wil die Iya mos op 'n punt bring mos man. Ek gaan jou op 'n punt bring. you to my point.') $==\left({ }^{\prime} N o\right.$, no, no. I want to bring my brother to my point. I'll bring

31. Rasta 1: InI kom Asher mos.

('You are Asher(ing) of course.')

32. Jeremy: Op Asher, dai's Robbin [inaudible] Hy doen dan nou die teenoorgestelde wat hy moet gedoen het. Nou mens kyk nog altyd vir hom [inaudible].

('On Asher, that's Reuben [inaudible] He's doing the opposite of what he should do. Now people are still looking at him.')

33. Jaak: Hy is nou sewe meer slegter wat $==$ ('He is now seven times worse than') $==$

34. Researcher: $==$ As gevolg van dai?

$$
==(\text { 'Because of that } ? \text { ') }
$$

Rasta 1 acknowledges Jeremy's claim to seniority as a Rastafarian, and acknowledges Jeremy's further argument that he earned a special birthright when he converted to Rastafarianism. He however asks that Jeremy not pry into other people's business, because he should not forget that a lot of other equally sinful activities are occurring around InI ('us') (line 15). Jeremy

\footnotetext{
${ }^{5}$ It is important to note here that Jeremy may not describe his birth as an Asher correctly or accurately in relation to Reuben. Reuben was the first-born son of Jacob, Gad was the seventh son, and Asher the eighth, according to Genesis 29:31-30:24. This means that Reuben should be superior. A discrepancy then arises: It would seem that there is a gap in Jeremy's knowledge about the distinction between the tribes and the interpretation of when an Asher is born. It would seem that perhaps the way he has been apprenticed into Rastafarianism has led him to provide a different interpretation of the ranking of the sons of Jacob. This goes unchallenged by Rasta 1, who is younger than Jeremy. Unfortunately, I could not elicit on what basis Jeremy and other Rastafarians identify themselves and each other with different sons of Jacob and other tribes of Israel. I will need to return to the field to collect more data.
} 
argues that he does overstand, but that he tried to expose the illicit activities of the young Rastafarian.

In the next extract, we see how the Rasta, who defends his 'brother', begins to reason about the ethics of sin by drawing on what the Bible says and forming conclusions regarding sin and the consequences of his friend's actions. He begins to undergo "Reasoning", that is to say, the moment when Rastafarians, Idren ('brethren'), quote scripture and argue about the politics of judgments.

\section{Extract 3:}

20. Rasta 1: Nai InI hoor, InI hoor. [inaudible] Kyk Iya niks wat die Rasta deusdae doen Iya verbaas my nie Iya. Hoor die man. Want even though, even though ons like a certain sacrifice gemaak het Iya, tot bekeering gekom het sien die man, is, is, hoe ka ek sê, is daar niemand wat sonder sin is nie Iaya

('No we hear, we hear. Look my brother nothing that the Rasta does today surprises me my brother. Because even though, even though we made a certain sacrifice my brother, we converted ourselves you see, how can I put it, nobody is without sin my brother.')

21. Rasta walking past our formed circle: Rastafari Lord! Blessed!

22. Researcher: Hoesit? [Greeting back]

('Howzit.')

23. Rasta 1: So, even though Iya ons hou dai vow Iya, sien die man. Hy try om ons se life a privilege te maak, ons liewe Iya. As sin not altyd tussen ons is, ons moenie vergetie, die tye as Jah ons almal, dan sien hy nie Rasta and whatever people boe ons nie Iya, over die man wat InI sê? Die tyd wannee Jah judge dan judge hy jou met jou dreadlocks net soes dai man met sy [inaudible]. Over die man? Hy sal nie nou hier is certain people en hie's certain people nie $==$

('So, even though my brother we keep that vow my brother, you see. He tries to make our life a privilege to live my brother. If sin is always amongst us, don't forgot, the time when God judges everybody, then he doesn't only see Rastafarians and whatever people above us my brother, do you understand? The time when God judges then he will judge your dreadlocks, just like he will judge that other man with his. Do understand? He will not say here is certain people and there are not certain people') $==$

24. Jaak: $==$ equal, ja equal $\mathrm{ja}==$ ('Equal, yes equal yes') ==

25. Rasta 1:

26. Jaak:
One people as $==$ ('We people as') $==$ equal people $\mathrm{ja}==$ ('Equal people yes')

In the above extract, Rasta 1 continues to comment on the ethics of his brother's actions. Firstly, he argues that he is not surprised nowadays by the actions of the Rastafarian (Iya, niks wat die Rasta deusda doen Iya verbaas my nie Iya, line 20). He suggests that even though they as Rastafarians have repented and converted to their religion, nobody is really without sin. At this moment of moral disciplining, a Rastafarian walks past our interactional circle and greets us all, "Rastafari Lord! Blessed". Again, I fell foul of my ignorance of Rastafarians and the cultural nuances of their multilingual voices: I once again misunderstood the greeting as I reciprocated 
with a Hoesit? 'Howzit' in Kaaps. I failed once again to successfully produce the correct greeting. Secondly, Rasta 1 starts to appeal to beliefs and principles he and his fellow Rastafarians swore to when they converted to Rastafarianism (see line 23). Thirdly, Rasta 1 relates the violation of ethics and disruptive religious experiences to the final judge and judgment time, and states that everybody is eventually judged according to what he did wrong or did not do.

At the end of the conversation, our interlocutor, the moral defender of the young Rastafarian, asks that all Rastafarians should just be for each other, and that he will continue to pray for his young sakman. I inadvertently agree: $J a$, ja (line 46). But Jeremy argues that the manner in which their interlocutor has reasoned about the sin committed by the young sakman makes him (Jeremy) the one that has committed the ethical crime. He suggests that the Rastafarian is die hangpaal ('the gallows'), and that he knows Rasta 1 wants to hang him (Ek wiet djy wil my hang, translated as 'I know you want to hang me'). Of course, our interlocutor disagrees and argues that Jeremy is really in the wrong for accusing his friend and saying he is seven times worse than what he previously was. In response to this, the Rastafarian makes his final point before he leaves the circle: He argues that even though Jeremy has raised good ethical objections, he should not forget that Jah ('God') has already interceded and that:

Jah is nou in dai Iya, hoor die man? Lyk my djy maak Jah in nou dai. Jah is nou in Iya. Dai man is sewe keer slegter, but sy package is uitgesit vir hom, sien die man. Vir een en elke sin wat djy comment Iya is daar punishment Iya.

('God is in that brother, do you hear? It seems you want to bring God in that situation. God is in you my brother. That man may be weaker, but a plan has already been set for him, do you see. For each and every sin you comment on my brother there is punishment my brother.')

The exchange in the previous extracts provides an interesting window onto the manner in which multilingualism amongst Rastafarian-herbalists unfolds. Firstly, with the exception of the Researcher, it is quite clear that Jeremy and Jaak command a multilingual repertoire that, depending on the topic and the person encountered, is able to enregister stereotypical character performances through Jamaican Patois and Kaaps. Secondly, it is through these two varieties that we see both social and cultural dimensions of their multilingual voices emerge within the interactional space. And thirdly, the use of both language varieties allows for meaning-making and successful cross-cultural communication. Thus, when it came to discussing in-group issues such as Rastafarian moral principles and ethics, interlocutors use Kaaps and Jamaican Patois; however, in the interaction with customers they use whatever language variety, style, register and accent they have selected to enregister their personae and successfully communicate with their customers.

\section{Conclusions}

The findings in this paper suggest that the multilingual voices of the Rastafarian-herbalists are tied to linguistic and non-linguistic resources in the small spaces where they trade. Those resources help shape the local multilingual calls and descriptions of the herbs the Rastafarianherbalists sell. The analysis has revealed that the multilingual encounters with customers are achieved through the enregisterment of local identities for the sake of cross-cultural multimodal communication. In other words, the Rastafarian-herbalists use multilingual and multimodal communication to their advantage not only to achieve a simpatico in cross-cultural 
communication, but also draw on their multilingual repertoires to identify with their customers. They thus enregister two types of identities, depending on the situation of interaction and topic: on the one hand, it seems that in conversations with customers that they would draw on their multilingual repertoires to enregister a herbalist identity or persona to achieve successful crosscultural communication, and, on the other hand, where it concerns topics and issues directly related to Rastafarianism, Jamaican Patois and Kaaps would be deemed important local languages to be used to manage interactions and conversations. In those instances, our Rastafarian-herbalists would enregister stereotypical characteristics of their Rastafarian identities.

The Rastafarian-herbalists' performance of multilingualism, and by extension how they enregister their voices in the way that I have reported here, is indicative of the work sociocultural linguists have to do to secure acceptance and recognition from those who trade and live on the margins. In the short time I spent with my research participants, it became apparent to me that the manner in which they enregister their multilingual voices is far from a unitary or singular phenomenon. They have put forward a theory of multilingualism that privileges linguistic hybridity and inclusivity. They have to have that theory if they are to sell their herbs. However, there is an extra aspect to why they privilege hybridity and inclusivity in their multilingual communication: they are aware of their own limitations and creativity, and they foreground their multilingual voices in multimodal communication; never undermining the possibilities that come with modalities that demonstrate to them the variegated multilingual interactions that they have grown accustomed to in the small subway space. That small space has become a test tube for a multilingual simpatico that requires that they are flexible in how they use multilingual forms and functions. They refrain from homogenizing multilingualism, never slipping into managing multilingualism as a quantitative experience but rather as an enmeshment of register, styles, speech practices and language varieties that help with meaningmaking and successful cross-cultural communication.

\section{References}

Agha, A. 1999. Register. Journal of Linguistic Anthropology 9(1/2): 216-219.

Agha, A. 2007. Language and social relations. Cambridge: Cambridge University Press.

Appadurai, A. 1996. Modernity at large: Cultural dimensions of globalization. Minneapolis: University of Minnesota Press.

Aronin, L. and D. Singleton. 2008. Multilingualism as a new linguistic dispensation. International Journal of Multilingualism 5(1): 1-16.

Bauman, R. 2001. The ethnography of genre in a Mexican market: Form, function, variation. In P. Eckert and J. Rickford (eds.) Style and sociolinguistic variation. Cambridge: Cambridge University Press. pp. 57-77.

Bauman, R. 2004. A world of others' words: Cross-cultural perspectives on intertextuality. Oxford: Blackwell. 
Blignaut, J. 2014. 'n Ondersoek na die taalgebruik in die Son as verteenwoordigend van Kaapse Afrikaans. MA thesis. Stellenbosch: Stellenbosch University.

Blommaert, J. 2003. Commentary: A sociolinguistics of globalization. Journal of Sociolinguistics 7(4): 607-623.

Blommaert, J., J. Collins and S. Slembrouck. 2005. Spaces of multilingualism. Journal of Language and Communication 25: 197-216.

Blommaert, J. and J. Dong. 2010. Ethnographic fieldwork. Clevedon: Multilingual Matters.

Blommaert, J. 2010. The sociolinguistics of globalization. Cambridge: Cambridge University Press.

Bosch, T. 1996. The making of I-story: Rastas in Cape Town. Honours thesis. Cape Town: University of Cape Town.

Chawane, M. 2012. The Rastafari movement in South Africa: Before and after apartheid. New Contree 65: 163-188.

Collins, M., S. Slembrouck and M. Baynham (eds.) 2010. Globalisation and language contact. London: Continuum.

Coupland, N. (ed.) 2010. The handbook of language and globalization. United Kingdom: Wiley-Blackwell.

Dong, J. 2011. Discourse, identity, and China's internal migration: The long march to the city. Bristol: Multilingual Matters.

Fabian, J. 1983. Time and the other: How anthropology makes its object. New York: Columbia University Press.

Farfan, J. 2003. "Al fin que ya los cueros no van a corer": The pragmatics of power in Hnahnu (Otomi) markets. Language in Society 32: 629-658.

French, B. M. 2001. The symbolic capital of social identities: The genre of bargaining in an urban Guatemalan Market. Journal of Linguistic Anthropology 10(2): 155-189.

Gardner, M. and M. Martin-Jones (eds.) 2012. Multilingualism, discourse, ethnography. London: Routledge.

Gastrow, V. and R. Amit. 2013. Somalinomics: A case study on the economics of Somali informal trade in the Western Cape. ACMS Research Report. Johannesburg: Wits University.

Goebel, Z. 2011. Talking about mediated representations: Exploring ideologies and meanings. Text and Talk: An Interdisciplinary Journal of Language, Discourse \& Communication Studies 31(3): 293-314.

Goffman, E. 1981. Forms of talk. Oxford: Basil Blackwell. 
Geertz, C. 1975. The interpretation of cultures: Selected essays. London: Hutchinson.

Gupta, A. and J. Ferguson. 1997. Anthropological locations: Boundaries and grounds of a field science. Berkeley: University of California Press.

Heller, M. 2007. Multilingualism and transnationalism. In P. Auer and L. Wei. (eds.) Handbook of multilingualism and multilingual communication. New York: Mouton de Gruyter.

Hendricks, F. 2012. Illuminating the neglected: A view on Adam Small's literary integration of Kaaps. Tydskrif vir Letterkunde 49(1):95-114.

Haviland, J. B. 2009. Little rituals. In G. Senft and E.B. Basso (eds.) Ritual communication. USA: Berg.

Haviland, J. B. 2011. Who asked you, condom head? Anthropological Quarterly 84(1): 235264.

Jaffe, A. (ed.) 2009. Stance: Sociolinguistic perspectives. Oxford: Oxford University Press.

Kapchan, D. 1996. Gender on the market: Moroccan women and the revoicing of tradition. Philadelphia: University of Pennsylvania Press.

Lefebvre, H. 2004. Rhythmanalysis: Space, time and everyday life. London: Continuum.

Lindenfeld, J. 1978. Communicative patterns at French marketplaces. Semiotica 23(3/4): 278290.

Lindenfeld, J. 1990. Speech and sociability at French urban marketplaces. USA: John Benjamins Publishing.

Manget-Johnson, C. A. 2008. Dread Talk: The Rastafarians' linguistic response to societal oppression. MA thesis. Georgia: Georgia State University.

Malinowski, B. 1922/1961. Argonauts of the Western Pacific: An account of native enterprise and adventure in the Archipelagoes of Melanesian New Guinea. London: Routledge and Paul.

Newell, S. 2009. Enregistering modernity, bluffing criminality: How Nouchi speech reinvented (and fractured) the nation. Journal of Linguistic Anthropology 19(2):157-184.

Oosthuizen, G. 1990. Rastafarianism. Honours thesis. KwaZulu-Natal: University of Zululand.

Pennycook, A. and E. Otsuji. 2015. Metrolingualism. London: Routledge.

Roth-Gordon, J. 2009. Conversational sampling, race trafficking, and the invocation of the Gueto in Brazilian hip-hop. In H.S. Alim, A. Ibrahim and A. Pennycook (eds.) Global linguistic flows: Hip-hop cultures, youth identities, and the politics of language. London: Routledge.

Small, A. 1972. Adam Small in gesprek met Ronnie Belcher. In Gesprekke met Skrywers 2. Kaapstad, Johannesburg: Tafelberg-Uitgewers. pp. 93-105. 
Small, A. 1987. Kitaar my kruis. (3 ${ }^{\text {rd }}$ edition). Pretoria: HAUM-Literêr.

Tolsi, N. 2011. Rise of the Rastafarian. Mail and Guardian. Available online: http://mg.co.za/article/2011-10-14-the-rise-and-of-rastafari (Accessed 22nd November 2016). Weber, J-J and K. Horner. 2011. Introducing multilingualism. A social approach. Abingdon, Oxon: Routledge. 